\title{
Perceived organisational justice among academic employees at a selected higher learning institution
}

\author{
Nethavhani, Andani \\ Maluka Harriet Rivalani \\ University of Limpopo, South Africa
}

\begin{abstract}
Keywords
Organisational justice; Academic employees; Distributive justice; Procedural justice; Interactional justice, Fairness
\end{abstract}

\begin{abstract}
Organisations depend on employees as crucial resources to execute duties aimed at realisation of organisational objectives. Organisational justice has been found to be a major predictor of employees' performance and wellbeing. Studies found that employees tend to view justice in a different manner and that majority of employees tend to enjoy their work when they perceive that organisational justice exist within their organisation. The objective of this study was to examine the academic employees' perceptions of organisational justice at a selected higher learning institution.

A descriptive quantitative research approach was adopted in this study. A structured questionnaire developed by Colquitt (2001) was used to collect data from a convenient sample of 50 academic employees. The questionnaire consists of 20 items measuring three dimensions of organisational justice (procedural justice, distributive justice, and interactional justice) rated on a 7point Likert scale. The collected data was analysed using the Statistical Package for the Social Sciences (SPSS) 26.0 published by the International Business Machines (IBM).

The research findings revealed that in general, a slight majority of the respondents perceived some form of organisational justice to exist within their organisation (mean of 4.64). Although similar results were found in terms of the three dimensions of perceived organisational justice (4.19 for procedural justice, 5.14 for distributive justice and 4.78 for interactional justice), some form of injustice was reported to exist in relation to procedural justice. The study recommends that future researchers should continue to explore all the prospects of organisational justice in higher institutions of education.
\end{abstract}

\section{Introduction and background}

Organisations depend on employees as crucial resources to execute duties aimed at realisation of organisational objectives. Organisational justice has been found to be a major predictor of employees' performance and wellbeing (Ledimo, 2015). Organisational justice refers to the "just and fair manner in which organisations treat their employees", hence the terms "justice" and "fairness" tend to be used interchangeably (Eib, 2015:1).

Studies found that employees tend to view justice in a different manner and that majority of employees tend to enjoy their work when they perceive that organisational justice exist within their organisation (Fernandes and Awamleh, 2006). Most studies conducted on the construct organisational justice indicate that it has an impact on organisational outcomes such as employee motivation, commitment, satisfaction, talent attraction and retention, employee and organisational performance, leadership, diversity management and ethical behaviour (Ledimo, 2015).

Wolfe, Rojek, Manjarrez and Rojek (2018) asserted that employees' perceptions of organisational justice could prevent counterproductive behaviour of employees, meaning that organisational justice could influence the behaviour and attitudes of employees. It can therefore be inferred that employees' perceptions of justice may result in employees' engagement in desirable behaviour, while perceptions of injustice may result in employees' engagement in undesirable behaviour.

Moreover, Gracia, Torress, Valázquez, Muñoz and Naranjo (2015) emphasised that one of the major roles that organisational justice plays in an organisation include facilitating organisational change and keeping the organisation as a unit. Baldwin, (2016) indicated that any organisational change in any organisation can be seen as intimidating by employees and therefore, careful application is needed to 
overcome feelings of distrust and loss of sanctuary. Research showed that employees' perceptions of organisational justice is one of the important areas that human resource professionals should consider in an attempt to fulfil both organisational and employees' desires (Coetzee, 2005).

\section{Problem statement}

Organisational justice is crucial in any organisation for the purposes of keeping well-skilled and well-experienced employees, however, it appears that many organisations including institutions of higher learning in South Africa have not mastered the concept of organisational justice as they continue to give the same treatment they perceive as fair to their employees (Colquitt, 2012).

Baldwin (2016) pointed out that organisational justice seems not to bet practiced in many organisations and this results in leads to high employment turnover and less job satisfaction among employees. Garcia et al. (2015) asserted that many organisations are losing their most skilled and wellexperienced employees as a result of employees' perceptions of injustices. This is supported by Colquitt (2001) by mentioning that many organisations are taken to court because of failure to practice fair procedures, follow the set rules and procedures as well as failing to adhere to policies. All these naturally lead to employees' perceptions of injustices in the organisation.

Therefore, the purpose of this study was to examine the academic employees' perceptions of organisational justice at a selected higher learning institution. The main question guiding the study was: what are the academic employees' perceptions of overall organisational justice and their perceptions of the organisational justice dimensions (distributive, procedural and interactional justice)?

\section{Literature review \\ Theoretical background}

The term organisational justice was invented by French (1964) to describe employees' perceptions of fairness in organisations (Karriker and Williams, 2009). Specifically, organisational justice is concerned with the ways in which employees determine if they have been treated fairly in their jobs and the ways in which those determinations influence other work-related variables (Johan, 2013).

O'Neill and Hastings (2011) mentioned that organisational justice can be classified into two, namely, interactional justice and organisational justice. Interactional justice comprises of interpersonal justice and informational justice, while organisational justice comprises of distributive justice and procedural justice. However, various authors agree that organisational justice is based on three key components, which are used to evaluate fairness, namely, distributive, procedural and interactional justice (Greenberg, 1990; Restubog, Garcia, Toledano, Amarnani, Tolentino and Tang, 2011).

Distributive justice involves an individual's perceptions of fairness with regards to the distribution of resources and outcomes in the organisation (Greenberg, 1990; Williamson and Williams, 2011). Procedural justice refers to the perceived fairness of the organisational procedures used to make decisions relating to the outcome decisions (Coetzee, 2005; Fernandes and Awamleh, 2006; Williamson and Williams, 2011). Interpersonal justice as one aspect of interactional justice represents the extent to which managers and supervisors treat people with dignity and respect while informational justice clearly explains the reasons for their decisions ( $\mathrm{O}^{\prime}$ Neill and Hastings, 2011; Xie and Dai, 2016; Vakili, Safarnia and Millahosseini, 2014).

Coetzee (2005) argued that organisations are composed of human beings who can be regarded as social beings, meaning that it is important organisations to create settings in which employees are able to interact socially. One aspect that is considered important in human social interaction is justice (Coetzee, 2005). Therefore, for the purpose of this study, Social Exchange Theory and Equity Theory were perceived as being appropriate in explaining perceptions of organisational justice or injustice.

\section{Social Exchange Theory}

Social exchange theory is regarded as one of the most important theories for understanding behaviour of employees in the workplace (Cropanzano and Mitchell, 2005). The social exchange theory is based on four premises as outlined below:

"Exchange interactions result in economic and/or social outcomes;"

"These outcomes are compared over time to other exchange alternatives to determine dependence on the exchange relationship;" 
"Positive outcomes over times increase organisations' trust of their trading partner(s) and their commitment to the exchange relationship;"

"Positive exchange interactions over time produce relational exchange norms that govern the exchange relationship" (Lambe, Wittmann and Spekman (2001: 6)

This means that economic and socio-emotional resources are two types of resources in exchange which could exist in an organisation. The two parties in the exchange relationship may compare the social and economic outcomes of their interactions on a continuous basis, and positive economic and social outcomes may increase the parties' trust of each other and commitment to sustaining the exchange relationship while negative economic and social outcomes may a put a strain on the exchange relationship (Lambe et al., 2001). This suggests that in the economic and social exchange between employees and the organisation, employees may weigh the costs and benefits they are receiving for their hard labour, and the norms of reciprocity will determine their perceptions in terms of whether organisational justice or injustice prevails (Palmer, Komarraju, Carter and Karau, 2017).

\section{Equity Theory (EqT)}

Adams' (1963) equity theory provides a useful understanding into the importance of perceptions of fairness in the workplace (Ryan, 2016). According to Hatfield, Walster and Berscheid (1978), equity theory is based on the four propositions outlined below:

People seek to maximise pleasure and minimise pain, making them to be concerned with the rewards and punishments they receive in social relationships.

Society tends to persuade people to behave fairly and equitably, resulting in rewarding those who treat others equitably and punish those who treat others inequitably.

People are most comfortable when they perceive that they are approximately receiving what they deserve from life, love, and work.

In inequitable relationships, people tend to reduce their distress by either restoring psychological or actual equity, or by abandoning the relationship.

Griffin, Phillips, and Gully (2016) indicate that in the working environment, the equity theory focuses on the social comparison's employees tend to make between their inputs and the outputs they receive as well as the inputs and outputs of their comparison-others, and these comparisons form basis of their perceptions in terms of whether there is equity or inequity. The inputs that employees could consider include amongst others their performance, loyalty, commitment, skills, seniority, personal sacrifice, and the degree of responsibility; while outputs include financial rewards, benefits, praise, recognition, promotion opportunities, conducive work environment and a sense of achievement (Robbins, Judge, Odendaal and Roodt, 2014).

When employees perceive that there is dissimilarity in the relationship between their inputs and outputs with their comparison-other's inputs and outputs, they would experience feelings of inequity (Griffin et al. 2016). In line with the equity theory, employees who perceive dissimilarities in relative to their inputs are more likely to view that as being unfair or unjust - thus, there is no organisational justice. (Bourdage, Goupal, Neilson, Lukacik and Lee, 2018)

As previous research revealed that organisational justice is comprised of different dimensions (Greenberg, 1990; O'Neill and Hastings, 2011; Restubog et al., 2011), Colquitt (2012) asserted that in order to understand how organisational justice can influence employees' attitudes and behaviours, it should be treated as a multi-dimensional construct or by aggregating distributive, procedural, interpersonal, and informational justice. Therefore, it is imperative to focus on how the two theories assist in explaining each dimension of organisational justice.

Distributive justice is based on the reciprocity principles of social exchange theory and the principles of equity theory as employees tend to assess the equity of outcome allocation in order to establish whether there is fairness or justice in terms of the outcomes they are receiving in relative to their inputs. The outcomes could be in a form of salaries, benefits, promotion as well as career advancement opportunities; while inputs include employees' educational qualifications, skills, abilities, and efforts (Trevor, 2009). Ledimo (2015) added outcomes such as allocation office space, budgets, computers, telephones, or company cars to enable employees to achieve organisational goals. 
Procedural justice is concerned with the benefits of accuracy and the costs of adjudication, and not solely costs and benefits (Colquitt, 2001). In line with the social exchange theory with regards to the importance of creating an environment that will enable employees to interact socially, procedural justice is deeply entwined with the powerful idea that a process that guarantees rights of meaningful participation is an essential prerequisite for the legitimate authority of action-guiding legal norms (Cropanzano and Molina, 2015). Trevor (2009) indicated that employees' perceptions of procedural fairness can be enhanced when employees are provided with the opportunity to voice out their concerns before taking any decision in the organisation that could affect them.

According to Kılıç, Bostan and Grabowski (2015), interactional justice is characterised by the sensitivity, politeness and respect employees receive from their superiors during procedures; this serves primarily to alter reactions to outcomes because sensitivity can make employees feel better even if the outcome is unfavourable. This implies that justice and fairness based on interactional justice are primarily related to how one person treats another in the work context. This may be relationships between employees and their managers or among themselves as colleagues (Ledimo, 2015).

Therefore, in line with social exchange theory, when employees perceive unfairness in relative to the socio-emotional outcomes they receive, they are more likely to perceive prevalence of organisational injustice (Lambe et al., 2001; Palmer et al., 2017). Similarly, in line with the equity theory, when employees perceive inequity in the treatment, they receive in relative to comparison other, they will have perceptions of organisational injustice or unfairness (Bourdage et al., 2018).

Restubog et al. (2011) indicated that in line with the social exchange theory and equity theory principles of reciprocity, when employees sense some form of unfairness from the organisation, supervisors, or co-workers, they may engage in negative behaviours, including withdrawal behaviour, lateness, intentional misuse of work time, harassment, and turnover intentions. However, social exchange quality, which involves a leader and a subordinate relationship, results in perceptions of organisational justice (Karam, Hu, Davison, Juravich, Nahrgang, Humphrey and DeRue, 2019).

\section{Empirical research findings}

Previous studies conducted on organisational justice revealed that positive relationships exist between organisational justice and the following variables; organisational trust (Kernan and Hanges, 2002; Aboagye, 2015; Oh, 2018), job satisfaction (Bryman, 2012; Banks, Patel and Moola, 2012; Tahayneh, 2014), employee engagement (Al-Zu'bi, 2010; Kravina et al, 2014), organisational commitment (Jameel, Mahmood and Jwmaa, 2020), deviant behaviour (Hagedoorn, Buunk and Van de Vliert, 1998; Jaakson, Vadia, Baumane-Vitolina and Sumilo, 2017; Hany, Hassan and Badran, 2020) and employee productivity (Ahmadi, Ziaei and Sheikhi, 2011; Banks, Patel, and Moola, 2012; Aboagye, 2015).

Jaakson et al. (2017) emphasised the importance of enhancing organisational justice at the workplace in an attempt to reduce employees' negative behaviours. Their research discovered that when employees perceived some form of injustices at their workplace, they are more likely to engage in deviant behaviours such as theft, deception, concealment, and sabotage (Jaakson et al, 2017). Hagedoorn et al. (1998) found that employees are likely to leave the organisation, report sick while not sick and put little effort at work when they perceived organisational injustices.

Not much research seemed to have been conducted in the higher education organisations, especially in South Africa (Bell and Barkhuizen, 2011). However, Aboagye (2015) indicated that in the education setting, perception of distributive inequality among academic staff is disconcerting and leads to negative feelings of anger among employees. The forms of inequality found to exist were in relation to amongst others, staff promotions, high grade delegations and other awarding systems (Aboagye, 2015).

A study conducted by Aslam, Shakir and Bugti (2020) among academic employees at public universities of Punjab found that academic employees tend to engage in negative behaviour when they perceived that their working environment is unjust. It was suggested that creating a supportive work environment based on principles of fairness or justice may assist to avoid negative emotions and deviant behaviours among employees (Aslam et al., 2020).

Research discovered that higher education in Asia is influenced by globalization, resulting in two types of structural inequality, namely; where differences of institutions and nations will be larger due to different types of power that global linking institutions and nations possess in higher education (Yang 
and Chia Nan, 2017) and where the stratification among higher education institutions in a nation will also be larger, leading to universities favoured by national governments possessing many more resources than those not chosen (Ahmadi, Ziaei, and Sheikhi, 2011). Aboagye (2015) indicated that this inequality causes feeling of guilt and dissatisfaction in employees.

It is therefore reasonable for educational institutions to distribute awards, remunerations, benefits, job assignment and delegations fairly among employees or academic staffs as it may affect staff performance positively (Cohen-Charash and Spector, 2001). Karriker and Williams (2009) affirm that an improvement in the perception of justice among employees increases performance. On the other hand, an unfair treatment may lead to job negligence, organisational incompatibility and staff resistance to decisions and applications (Cohen-Charash and Spector, 2001; Karriker and Williams, 2009; Yang and Chia Nan, 2017). It is apparent that the negative outcomes of perceptions of injustice among academic employees may have negative detrimental effects on students (Powell, 2010). Therefore, any action aimed at enhancing employees' perceptions of organisational justice in any higher education institution is of utmost importance.

\section{Research methodology \\ Research design}

A quantitative research design was adopted in this study as it enabled the researchers to gather numerical data and generalising it across groups of people to explain a phenomenon under study (Babbie, 2010). This study is a quantitative study because structured questions were used to collect data on the academic employees' perceptions of organisational justice (Bryman, 2012). The current study is also descriptive in nature as were made to describe in detail academic employees' perceptions of organisational justice (Kumar, 2011).

\section{Population and sampling}

At that point, the population of this study comprised of 59 academic employees from one school at a selected university. A non-probability sampling strategy, in a form of convenience sampling was used to draw the sample. A convenience sampling method which involves a method through which the researcher selects a sample based on the participants' willingness and availability to participate in the study (Bryman, 2012). At the end, a convenience sample of 50 (84.7\% of the population) participated in this study.

Majority of $66 \%(n=33)$ of the respondents were males while $34 \%(n=17)$ were females. Majority of the respondents were between $41-50$ years $(38 \%, n=19)$, followed by $36 \%(n=18)$ who were between $31-40$ years, then $16 \%(8)$ at the age of 51 and above, and lastly 10\% $(n=5)$ were between 21-30 years. Majority of $92 \%(n=46)$ had postgraduate qualifications while $8 \%(n=4)$ had undergraduate qualifications. Majority of $40 \%(n=20)$ of the respondents have been working at the institution for $1-5$ years, $34 \%(n=17)$ for a period of $5-10$ years, $14 \%(7)$ for more than five years and $12 \%(n=6)$ for less than a year.

\section{Data collection}

The ethical clearance was obtained from the institution before data collection. Structured questionnaires were used to collect data. O'Neil and Adya (2009) emphasised that questionnaires are useful in obtaining large amounts of information from a large number of people in a short period of time and in a relatively cost-effective way. Questionnaires were distributed in the participants' offices at their most convenient time and collection of completed questions occurred on the date agreed upon.

The questionnaire consisted of two sections; Section A consisted of five demographic questions aimed at collecting information in order to describe the participants. Section B was comprised of 20 questions measuring organisational justice on a 7-point scale. Organisational Justice Scale is a valid and reliable scale developed by Colquitt (2001), reporting a reliability of 0.815 .

\section{Data analysis}

Data was analysed using the Statistical Package for the Social Sciences (SPSS) 25.0 published by International Business Machines (IBM). The data was coded and captured in a way that allowed interpretation and analysis. Descriptive statistics was used make sense of both demographic information 
and responses relating to organisational justice. Data was presented in the form of frequency tables, graphs, and charts.

\section{Results}

\section{Reliability of Organisational Justice Scale}

The reliability of the organisational justice scale and its dimensions were computed. Uma and Roger (2016) stated that the reliability of the measure is established by testing the consistency and stability of a measure. In this study, reliability was checked through Cronbach Alpha, a reliability coefficient that indicates how well the items in a set positively correlate to one another. The closer the Cronbach Alpha is to 1 , the higher the internal consistency reliability, reliabilities with less than 0.60 indicate poor consistency while those with $0.70-0.80$ are deemed as being acceptable and those above 0.80 are considered as very excellent (Uma and Roger, 2016). The organisational justice scale and its dimensions yielded good reliabilities with 0.815 for overall organisational scale, 0.82 for distributive justice, 0.797 for procedural justice and 0.845 for interactional justice were found. Table 1 depicts the reliabilities of organisational justice scale and its dimensions.

Table 1: Reliabilities of organisational justice scale and its dimensions

\begin{tabular}{|l|l|}
\hline Reliability Statistics \\
\hline Overall Organisational Justice & \multicolumn{2}{|l|}{} \\
\hline Cronbach's Alpha & N of Items \\
\hline .815 & 20 \\
\hline Distributive Justice & \multicolumn{2}{|l|}{} \\
\hline Cronbach's Alpha & N of Items \\
\hline .820 & \multicolumn{2}{|l|}{4} \\
\hline Procedural Justice & N of Items \\
\hline Cronbach's Alpha & 7 \\
\hline .797 & \multicolumn{2}{|l|}{} \\
\hline Interactional Justice & N of Items \\
\hline Cronbach's Alpha & 9 \\
\hline 845 & \multicolumn{2}{|l|}{} \\
\hline
\end{tabular}

\section{Descriptive statistics results}

In presenting and interpreting the results on employees' perceptions of organisational justice, the focus will be on each sub-scale. It should be noted that for the purpose of this study, each item with a mean of above 4 is considered as being perceived positively (justice prevails), and each item with a mean of below 4 , is considered as being perceived negatively (injustice prevails).

\section{Overall Organisational Justice}

Table 2 displays employees' overall responses, and academic employees reported positive perceptions of overall organisational justice as 17 of the 20 items used have a mean of above 4, with an overall mean of 4.64. Therefore, it can be concluded that the academic employees perceived the university's practices relating to overall organisational justice positively.

Table 2: Organisational justice descriptive statistics

\begin{tabular}{|c|c|c|c|}
\hline & $\mathrm{N}$ & Mean & Std. Dev. \\
\hline Have you been able to express your views and feelings during those procedures? & 50 & 3.98 & 1.478 \\
\hline Have you had influence over the outcomes arrived at by those procedures? & 50 & 3.92 & 1.482 \\
\hline Have those procedures been applied consistently? & 50 & 4.62 & 1.193 \\
\hline Have those procedures been free of bias? & 50 & 4.06 & 1.252 \\
\hline Have those procedures been based on accurate information? & 50 & 4.30 & 1.093 \\
\hline Have you been able to appeal the outcomes arrived at by those procedures? & 50 & 3.96 & 1.212 \\
\hline Have those procedures upheld ethical and moral standards? & 50 & 4.54 & 1.265 \\
\hline Do your outcomes reflect the effort you have put into your work? & 50 & 5.26 & 1.382 \\
\hline
\end{tabular}




\begin{tabular}{|l|l|l|l|}
\hline Are your outcomes appropriate for the work you have completed? & 50 & 5.18 & 1.137 \\
\hline Do your outcomes reflect what you have contributed to the organisation? & 50 & 5.12 & 1.100 \\
\hline Are your outcomes justified, given your performance? & 50 & 4.98 & 1.270 \\
\hline Has he/she treated you in a polite manner? & 50 & 5.02 & 1.464 \\
\hline Has he/she treated you with dignity? & 50 & 5.22 & 1.217 \\
\hline Has he/she treated you with respect? & 50 & 5.04 & 1.142 \\
\hline Has he/she refrained from improper remarks or comments? & 50 & 4.46 & 1.487 \\
\hline Has he/she been candid in his/her communications with you? & 50 & 4.52 & 1.015 \\
\hline Has he/she explained the procedures used to make job decisions thoroughly? & 50 & 4.96 & 1.160 \\
\hline $\begin{array}{l}\text { Were his/her explanations regarding the procedure used to make job decisions } \\
\text { reasonable? }\end{array}$ & 40 & & 1.239 \\
\hline Has he/she communicated details in a timely manner? & 50 & 4.66 & 1.255 \\
\hline Has he/she seemed to tailor his/her communications to individuals' specific needs? & 50 & 4.48 & 1.165 \\
\hline Valid N (listwise) & 50 & & \\
\hline
\end{tabular}

\section{Procedural Justice}

Items 1-7 measured procedural justice and the participants' overall results showed a mean of 4.19, which is slightly above 4 . Therefore, academic employees' perception in relation to overall procedural justice at the university is to a certain degree positive.

\section{Distributive Justice}

Distributive justice was measured by items 8-11 and the participants' overall results showed a mean of 5.14, which is considerably above 4 . Therefore, the results revealed that academic employees perceived that there is fairness when it comes to the distribution of resources and actual outcomes they receive for their efforts.

\section{Interactional Justice}

Items 12-20 measured interactional justice and the respondents' overall results yielded a mean of 4.78, which is slightly above 4 . This implies that academic employees perceived their immediate supervisor's ability to communicate and provide information in a positive way.

\section{Significance and limitations of the study}

The primary contribution of the study is that it contributes to the body of knowledge relating to organisational justice. As there seems to be limited research conducted on organisational justice in higher education institutions in the South African context, this study managed to address such a gap. However, there were some limitations that are worth mentioning.

Firstly, the sample size used in this study was not large considering the number of academic employees at the selected school, which prevent generalisation of the research findings. It is recommended that future research on organisational justice in higher education institutions focusses on a larger sample, and possible considers a comparison between public and private higher education institutions.

Secondly, overreliance on self-reported measures have subjected to the source of error, whereby participants answer questions based on what they perceive as a socially desired. It is therefore recommended for future research to use different research methods, either qualitative or mixed methods in order to gain more insights with regards to organisational justice in higher education institutions.

\section{Conclusion}

This study sought to measure the perceptions of academic employees towards organisational justice at a selected university. The findings from showed that majority of employees perceived that in general, organisational justice prevails within their organisation. However, it is worth noting that three of the seven items used to measure procedural justice were perceived in a negative way. Academic employees perceived that they are not provided with the opportunity to express their views and feelings about procedures, they have no influence over the outcomes arrived at and they are not provided with the opportunity to appeal should the outcomes arrived at by procedures are not perceived as being fair. 
It is therefore recommended for the institution to provide a platform for employees to express their views when decisions are made, especially those who could be affected as well as to appeal in case there are disagreements in terms of decisions made. The management should create an environment where clear communication channels about the procedures to be followed are in place.

\section{References}

Aboagye, E. 2015. A study of the dimensions of organisational justice which best predict employee trust and productivity in Ghanaian higher education institutions. Doctoral Thesis: University of Ghana.

Adams, J.S. 1963. Toward an understanding of inequity: Journal of Abnormal Psychology, 67: 422-436.

Ahmadi, F., Ziaei, M., \& Sheikhi, Z. 2011. Relationship between organisational justice and human resource: Interdisciplinary Journal of Contemporary Research in Business, 3(5): 728-750.

Al-Zu'bi, A. 2010. A study of relationship between organisational justice and job satisfaction: International Journal of Business and Management, 5(12): 102-109.

Aslam, H.D., Shakir, M. \& Bugti, F. 2020. Influence of organisational justice and perceived organisational support on deviant behaviour: an Islamic perspective: Al-Qalam, 25(1): 1-18.

Babbie, E. 2010. The practice of social research. Wadsworth: Belmont.

Baldwin, S. 2016. Organisational Justice. Brighton: Institute for Employment Studies.

Banks, J., Patel, C. J., \& Moola, M. 2012. Perceptions of inequity in the workplace: Exploring the link with unauthorised absenteeism. SA Journal of Human Resource Management, 10(1): 1-8.

Bell, E., \& Barkhuizen, N. 2011. The relationship between barriers to change and the work engagement of employees in a South African property management: SA Journal of Industrial Psychology, 37(1): 1-11.

Bourdage, J.S., Goupal, A., Neilson, T., Lukacik, E. \& Lee, N. 2018. Personality, equity sensitivity, and discretionary workplace behaviour: Personality and Individual Differences, 120: 140-150.

Bryman, A. 2012. Social research methods. United Kingdom: Oxford Press.

Coetzee, M. 2005. Organisational Justice. South Africa: University of Pretoria.

Cohen-Charash, Y. \& Spector, P.E. 2001. The role of justice in organisations: A meta-analysis: Organisational Behaviour and Human Decision Processes, 86(2): 278-321.

Colquitt, J.A. 2001. On the Dimensionality of Organisational Justice: A Construct Validation of a Measure: Journal of Applied Psychology, 89(3): 386-400.

Colquitt, J.A. 2012. Organisational justice. In S. W. J. Kozlowski (Ed.), The Oxford Handbook of Industrial/Organisational Psychology (Vol. 1, pp. 526-547). New York: Oxford University Press.

Cropanzano, R. \& Mitchell, M.S. 2005. Social Exchange Theory: An Interdisciplinary Review: Journal of Management, 31(6), 874-900.

Eib, C. 2015. Processes of Organisational Justice: Insights into the perception and enactment of justice. Doctoral Thesis, Sweden: Stockholm University.

Fernandes, C., \& Awamleh, R. 2006. Impact of organisational justice in an expatriate work environment: Management Research News, 29(11): 701-712.

Gracia, T.J.H., Torress, E.M., Valázquez, M.R.G., Muñoz, E.M. \& Naranjo, G.G. (2015). Organisational Justice: a vision by higher education academic staff. Global Journal of Management and Business Research; G Interdisciplinary, 15(3): 9-17.

Greenberg, J. 1990. Organisational justice: yesterday, today, and tomorrow: Journal of Management, 16: $399-432$.

Griffin, R.W., Phillips, J.M. \& Gully, S.M. 2016. Organisational behaviour: Managing people and organisations. United States: Cengage Learning.

Hagedoorn, M., Buunk, B. P. \& Van de Vliert, E. 1998. Opening the black box between justice and reactions to unfavourable outcomes in the workplace: Social Justice Research, 1(1): 41-57.

Hany, S.H., Hassan, R.M. \& Badran, F.M.M. 2020. Relation between organisational justice and workplace deviance behaviour among staff nurses: Egyptian Journal of Health Care (EJHC), 11(1): 248-259.

Hatfield, E., Walster, G.W. \& Berscheid, E. 1978. Equity: Theory and Research. Boston, MA: Allyn and Bacon.

Jaakson, K., Vadia, M., Baumane-Vitolina, I. \& Sumilo, E. 2017. Virtue in small business in small places: Organisational factors associated with employee dishonest behaviour in the retail sector: Journal of Retailing and Consumer Services, 34,168-176.

Jameel, A.S., Mahmood, Y.N. \& Jwmaa, S.J. 2020. Organisational justice and organisational commitment among secondary school teachers: Journal of Humanities and Social Sciences, 4(1): 1-6.

Johan, M. 2013. Procedural and Distributive Justice on Turnover Intention: An exploratory analysis: Interdisciplinary Journal of Contemporary Research in Business, 4(9): 182-191.

Karam, E.P., Hu, J., Davison, R.B., Juravich, M., Nahrgang, J.D., Humphrey, S. E. \& DeRue, D.S. 2019. Illuminating the 'face' of justice: A meta-analytic examination of leadership and organisational justice: Journal of Management Studies, 56(1): 134-171. 
Karriker, J.H, \& Williams, M. 2009. Organisational Justice and Organisational Citizenship Behaviour: A Mediated Multifoci Model: Journal of Management, 35(1): 111-135.

Kernan, M.C. \& Hanges, P.J. 2002. Survivor reactions to reorganisation: Antecedents and consequences of procedural, interpersonal, and informational justice: Journal of Applied Psychology, 87(5): 916-928.

Kılıç, T., Bostan, S., \& Grabowski, W. 2015. A new approach to the organisational justice concept: The collective level of justice perceptions: International Journal of Health Sciences, 3(1): 157-175.

Kumar, R. 2011. Research Methodology: A Step-by-Step Guide for Beginners. New Delhi: Sage Publications.

Kravina, L., Falco, A., De Carlo, A., Andreassen, C. \& Pallesen, S. 2014. Workaholism and work engagement in the family: The relationship between parents and children as a risk factor: European Journal of Work and Organisational Psychology, 23(6): 875-883.

Lambe, C.J., Wittmann, C.M. \& Spekman, R.E. 2001. Social Exchange Theory and Research on Business-to-Business Relational Exchange: Journal of Business-to-Business Marketing, 8(3): 1-36.

Ledimo, O. (2015). Development and Validation of an Organisational Justice Measurement Instrument for a South African Context: Journal of Business and Psychology, 5(1): 27-38.

Oh, S.-Y. 2018. Effects of organisational learning on performance: The moderating roles of trust in leaders and organisational justice: Journal of Knowledge Management, 1-19.

O'Neil, B., \& Adya, M. 2009. Knowledge sharing and the psychological contract: Managing knowledge workers across different stages of employment: Journal of Management Psychology, 22(4): 411-436.

O'Neill, T. A., \& Hastings, S.E. 2011. Explaining workplace deviance behaviour with more than just the "Big Five": Personality and Individual Differences, 268-273.

Palmer, J.C., Komarraju, M., Carter, M.Z. \& Karau, S.J. 2017. Angel on one shoulder: Can perceived organisational support moderate the relationship between the Dark Triad traits and counterproductive work behaviour? Personality and Individual Differences, 110: 31-37.

Powell, W.W. 2010. Understanding attrition and predicting employment durations of former staff in a public social service organisation: Journal of Social Work, 10: 407-435.

Restubog, S.L.D., Garcia, P.R.J.M., Toledano, L.S., Amarnani, R.K., Tolentino, L.R., \& Tang, R.L. 2011. Yielding to (cyber)-temptation: Exploring the buffering role of self-control in the relationship between organisational justice and cyberloafing behaviour in the workplace: Journal of Research in Personality, 45: 247-251.

Robbins, S.P., Judge, T.A., Odendaal, A. \& Roodt, G. 2014. Organisational behaviour: Global and Southern African perspectives. Cape Town: Pearson Education SA Ltd.

Ryan, J.C. 2016. Old knowledge for new impacts: Equity theory and workforce nationalisation. Journal of Business Research, 69: 1587-1592.

Trevor, T. B. 2009. Organisational justice, equity sensitivity, and workplace attitudes. Master's Thesis, Chattanooga: University of Tennessee.

Uma, S. \& Roger, B. 2016. Research methods for business: a skill-building approach: John Wiley publications, 5: 5-7.

Vakili, A., Safarnia, H., \& Millahosseini, A. 2014. Organisational Justice in family firms of Iran: International Journal of current Microbiology and Applied Sciences, 3(3): 782-790.

Williamson, K., \& Williams, K. J. 2011. Organisational justice, trust, and perceptions of fairness in the implementation of agenda for change: Radiography, 17: 61-66.

Xie, H. \& Dai, L. 2016. Review and prospect on interactional justice: Open Journal of Social Sciences, 4: 55-61.

Yang, J.C.-C., \& Chia Nan, I.-P.C. 2017. Organisational Justice in Higher Education: Perceptions of Taiwanese Professors and Staff: Contemporary Issues in Education Research, 231-240. 